\title{
ANOTHER DIMENSION TO CHILD LABOUR: COUNSELLING IMPLICATIONS
}

\author{
OMONI, G. E. PhD \\ Institute of Education, \\ Delta State University, \\ Abraka \\ email: egonomoni@yahoo.com \\ and \\ IJEH, S. U. Mrs \\ College of Education
}

Agbor

\begin{abstract}
The issue of child labour is an acclaimed universal phenomenon. This paper examines the reason for child labour, the types, problems, consequences and possible solution strategies. Specifically, the paper critically discusses the positive aspects of child labour and how it can be properly managed to the advantage of all. By working and contributing economically, children are showing solidarity with their families. The paper concludes by suggesting and recommending ways of positively managing child labour. Such include vast grassroots information campaigns and counselling on the hazardous effects of child labour and its economic values. It also discusses the roles federal/state governments can play through public education and enforcement of the universal basic education goals; introduction of a modified school curriculum that puts the recipients of child labour into consideration; creating and supporting rehabilitation and integration programmes and the enactment of penalties and sanctions against perpetuators negative child labour.
\end{abstract}

Key Words: Bonded child labour, child work, child trafficking, cultural practice, exploitation, child prostitution, rehabilitation, self-reliance.

\section{Introduction:}

Child labour has been the main thrust of universal discussion over a period of time. Journalists, psychologists, sociologists, politicians, philanthropists and even literary artists have deliberated on and sought for ways of stopping this exploitative and hazardous phenomenon to no 
avail. The developed, developing and under-developed countries of the world are all guilty of child labour. However, according to International Labour Organization (ILO) (1998), child labour is overwhelmingly a developing country phenomenon with Africa having the highest incidence. It further asserts that participation rates of child labour force are higher in sub-Saharan region, Nigeria inclusive. Since the period of industrial revolution, Charles Dickens (1812-1870) the author of "Oliver Twist" had the issue of child labour as his main theme. Today, the problem is still prevailing. Bequel and Boyden (1998) opine that all over the world, children are incorporated into a range of different employment relations either as wage labourers in factories or self-employed workers or are engaged in street trading.

The International Labour Organization (ILO) (1998) has estimated that 250 million of the world children between the ages of five and fourteen work. Human Right Watch Publications (2000) asserts that the age of children who engage in child labour ranges from four to seventeen years old. According to Oloko (1999) an estimated 8 million Nigerian children are said to be trapped under the yoke of child labour in spite of governments' effort at stopping it and ensuring the education of all children.

Dunapo (2002) citing Black (1993) and Ennow (1994) in Otubokun (2000) claim that children are involved in exploitative work when they are too young to do so. They further assert that the hours are too long and the work is too difficult for a small growing body. Hence Fatusi, Segun, Adeyemi and Odujinrin (2001) assert that adolescents are exploited under conditions that amount to a modern form of slavery. They rarely escape and are never in position to negotiate the conditions of their employment. Again, the International Labour Organization (ILO) (1998) estimates that the number of child labourers in Africa could surge from today's 80 million to over 100 million by the year 2015. This is as a result of a demographic explosion of impoverished people and inadequate levels of economic growth across Africa. According to Williams, Finke, Warren, Bazan, Walgen and Cohen (2005), work ranges from taking care of animals, planting and harvesting food, to being in many kinds of small manufacturing companies for auto repair, making of footwear and textiles. The authors further claim that more boys than girls work outside their homes. Girls often work as domestic maids. Being someone's house help can be very risky. Maids are cut off from friends and families. This is one reason why many youngsters do not attend schools. For instance, in Port Harcourt, a story had it that a housewife forced her domestic maid into a deep freezer for failing to open the gate on time. Many children in 
hazardous and dangerous job get injured or even die. Today's children will join the work force tomorrow but this might be an illusion since many would have been destroyed due to the incidence of child labour. The worst form of child labour and abuse are seen where children are forced into prostitution, sex work and drug peddling. ILO (1998) further emphasized that if the present trends continue, at least 400,000 children per year in sub-Saharan Africa aged 6-11 would remain out of school and join the pool of child labourers.

Despite these opinions that have been articulated over the years, the researchers are of the opinion that third world countries cannot do without child labour. Child labour is found all over the world. The proportion varies among countries and even among regions within these countries. This is because most families will move from hunger to some forms of sufficiency with the assistance from their children. Cruzador (1998), a young girl of about 15 yrs claims that working had taught her some valuable things such as ethical principles; how to live and how to accept responsibility.

This paper observes that the issue of stopping child labour has lingered on for a long time without possible success. An alternative dimension could be pursued and exploited to maximally tap the positive effects of child labour.

The topic is therefore discussed under the following subheadings: definitions of child labour, reasons for its occurrence in our environment, types, alternative dimension of child labour, counselling implications and suggestions.

\section{Definition of child labour:}

There is no universally accepted definition of child labour. According to William et al (2005) varying definitions of the term are used by International Organizations, nongovernmental organizations, trade unions and interest groups. To them child labour means work for children that harms or exploits them in some ways to physically, mentally, morally or by blocking their access to education. International Labour Organization (1998) sees child labour as some types of work performed by child below age 18 . Thus, child labourers are child workers between the ages of five and seventeen. CFMEU (2003) defines child labour as "making children to do work that is physically and mentally harmful and which interrupts their education or social development". However, it distinguishes child labour from child work. Some social scientists see "child work" as not objectionable while "child labour" is 
objectionable, exploitative and oppressive. Thus, by child work is meant work in which primary emphasis is on learning training or socialization (Hodges: 2001). As such, the work schedule is flexible, tends to be responsive to the developing capacity of the child. Though it is for learning, training and socialization, children are still being exploited and abused. Whereas the organization of African Unity in highlighting the rights of the child, states that even though every child ought to grow and develop in a free society in the spirit of understanding, tolerance, mutual respect and friendship among people and adults infringes on their rights. These researchers believe that not all work is bad. Children's work needs to be seen as happening along a continuum, with destructive or exploitative work at one end and beneficial work promoting or enhancing children's developments without interfering with their schooling, recreation and rest at he other end. (UNICEF, State of World's Children Report: 1997). These researchers support this point of view that there are some areas of work that need not negatively affect a child's development either socially, cognitively or morally.

\section{Reasons for Child Labour:}

Children work for different reasons. Poverty is widely considered the top reason why children work. However, there are other reasons, which include craze for wealth, lack of education/ignorance, indebtedness or bonded child labour, traditional practices, broken homes/divorce.

\section{Poverty:}

As earlier mentioned, poverty is widely considered the top reason why children work. International economic trends have even increased child labour in poor countries. In other words, parents' poverty and government's indebtedness, recession and unwise economic policies resulting in economic crises have encouraged child labour. Fatusi et al (2002) opine that economic hardships force some parents and guardians to sell or barter their children or abandon them. They further explain that these children are put into various income-generating activities for survival. Poverty is the backdrop for parents of lower socioeconomic status who expect an economic contribution from their children's labour. According to Richard (1988), parents 62 percent of the source of children's induction to employment. Child employment is seen as supporting financial resources for families. Lindert (1976) opines that children work to ensure the survival of their families and themselves. Adegoke (2003) asserts that many adolescents and young people start their working life too early and are unable to go to school. He further explains that they 
suffer from fatigue and a higher accident rate than adult workers. He concludes that these young people encounter new cultural patterns and hostile environments leading to mental/behavioural problems.

\section{Craze for Wealth:}

The exploitation of children for immediate wealth increase has been alarming, as middlemen have exploited the desperation and ignorance of parents. This is one of the fastest ways of swelling their pockets. Perpetual quest for profit is unending as these men use children for different forms of work as long as it benefits them economically. UNICEF state of the World's children's Report (1997) asserts that most of the world's child labourers are found in the informal sectors selling on the street, at work in agricultural farms and hiding in houses from media scrutiny. According to ILO (1998) 40\% of street children surveyed had been trafficked and are economically active. They are employed as sex workers, drug peddlers, car washers and bus conductors.

\section{Lack of Education/Ignorance:}

Orewere and Bargo (1997), opine that the Nigerian masses, like their other $3^{\text {rd }}$ world counterparts are today faced with problems that include hunger, poverty, disease, illiteracy, manipulation and lack of political power. Onyemuwa (1991) claims that while the advanced nations are succeeding in their efforts to eliminate illiteracy, the third world countries are not making any meaningful progress. Most parents are illiterates and do not know the importance of sending their children to school or are too poor to do so. Fatusi et al (2002) posit that the level of illiteracy among Nigerian youth is generally high due to a number of factors such as poverty and social cultural problems. Many of them are not aware of the fact that their children are sold into slavery or used for prostitution. The middlemen that come to them falsely present a better lifestyle for these children. Out of share ignorance, they inadvertently give them out for these hazardous and dangerous works. Fatusi et al (2001) explain that parents or guardians in rural areas give out their children who are taken to the urban areas and are either sold or lent out for a fee to be beer parlour or restaurant attendants, domestic servants or to brothels to work as prostitutes. Many families raise daughters solely to take over household duties in order to release the mother for paid labour. Such a cultural practice restricts $t$ he education of females and promotes child labour. Chemai (2005), among others asserts that parents of children who engage in child labour are mainly illiterates or semi-literates. He observes 
further that rural poverty, lack of employment or partial employment and illiteracy have given birth to majority of child labour problems.

\section{Indebtedness or Bonded Child Labour:}

Bonded child labour takes place when families receive an advance payment by handing over a boy or girl over to an employer. In most cases, the child cannot work off the debts nor can the family raise enough money to buy the child back. The expenses or interest are deducted from the child's earning in such amount that is almost impossible for the child to repay the debt. In some cases, the labour is generational that is, a child's grandfather or great grandfather was promised to an employment many years earlier with the understanding that each generation will provide the employer with a new worker - often with no pay at all. The money lender puts the child into bonded labour until the debt is paid. (The State of World's Children: 1997).

\section{Traditional practices:}

According to Hodges (2001), millions of Nigeria women face special problem of discrimination, abuse and exploitation in appalling circumstances. This is further emphasized by Orewere and Bargo (1997) who assert that many women suffer discriminatory practices that further lead them to low skilled jobs, earning low pay and low status. Dehumanizing widowhood rites are practised. The widow is treated as an inheritable part of the husbands' property. She is not allowed to have any of her husband's property. These problems compound risk of survival and create formidable obstacles for the development of women and their children. The widow has no choice than to send the children out to contribute to the welfare of the family as she cannot feed and educate the children adequately. The little ones have to go to work to augment for the family's economic power. Cultural norms in some communities see work as a rite of passage or a form of life education. Again, ILO (1998) asserts that traffickers take the advantage of the cultural tradition of fostering, where a poor rural family sends a child to live and work with a family in an urban area. Such children are forced to serve as domestic servants.

\section{Broken Home/Divorce}

The effect of divorce and separation on the welfare of the children is hazardous. Nwobi (1979) claims that the reluctance of husband and mothers in supporting themselves and their children often forces families of divorced mothers to suffer economic hardships. Children from broken 
homes are treated in discriminatory manners within the household by their step-mother/father who tends to give preference to his/her own children in distribution of household chores. These children do the worst forms of labour to keep up with family income. Some run away from home and prefer to fend for themselves. This led them into the hands of taskmasters. Eweniyi (2000) opines that continued disintegration of families makes children vulnerable to sexual assaults.

\section{Types of Child Labour}

\section{Sexual Exploitation:}

Sexual exploitation of children is a grave abuse of rights and is consequently deplored by the convention on the rights of children. Hodges (2001) asserts that commercial sexual exploitation has become a problem of special concern in Nigerian as many of them are already victims of HIV/AIDs and other sexually transmitted infections. Studies by Adedoyin and Adejoke (1995) UNICEF (1999) indicate that child prostitution is now common in towns in Nigeria with about ten thousand $(10,000)$ children involved in prostitution. In the last decade there has been large-scale trafficking of children and adolescent girls to Europe particularly Italy for work in sex industry while the boys work in mines and industries. Here they also do all kinds of menial jobs. The traffickers promise them legitimate and lucrative work. However on arrival, they are handed over to prostitution rackets. They are forced to engage in sex and odd work (including drug trafficking) to payoff tickets and accommodations (Human Right publication 2000).

\section{Child Work:}

Most child work occurs in agriculture, mining and in the informal sectors of the economy. While some of the children help in farming, fishing and cattle rearing to beef up the family economy, others work in mines and public settings, industries, workshop and in private households as domestic servants. In public settings, you see them as newspaper vendors, shop and markets stalls minder, car washers/watchers, cobblers scavengers and porters in the markets. According to UNICEF (2001) it has become increasingly common to find so called "any work" children, offering to carry out any type of menial tasks such as street hawking, mining, apprentices in workshops or work as bus conductors, iron benders and metal workers, carpenters, tailors, weavers, hairdresser's barbers and workers in the catering industries. For instance in Mali and Burkina Faso, children climb down shafts up to 80 meters deep to work in 
gold mines, (Hodges, 2000). There is no doubt that such end up physically and psychologically incapacitated.

\section{Alternative Dimensions to Child Labour (Positive Consequences)}

Millions of children around the world have to work to support themselves and families. "Save the children" believes that all children have the right to be protected from dangerous and exploitative work. The group does not believe in banning all children's work. This is because for some, it is a valuable art of growing up and banning it can drive them into more dangerous work. According to Cruzador (2001), "There is nothing wrong with work ... what is wrong is the way the children are exploited, beaten and sexually abused". We need a culture where children are no longer seen as problems but as people with rights and dignity who can make real contributions to society. There is need to listened to the various voices of children who do not want just the decry of the exploitative aspect of child labour but to be listen to and be worked with so as to encourage safe working environment for the children as they work in dignity. Gill (1990) warned against the complete eradication of child labour worldwide calling for a more "nuanced" view of the contribution of children to both family livelihoods and income. He posited that there are many reasons why work is a rite of passage or a form of life education. Children are opposed to exploitative dangerous work but they need to work with dignity to help their families and pay school costs. Children who engage in work have the opportunity of acquiring skills in various trades. This paves the way to self-reliance and self-sufficiency in this contemporary society. In the rural areas children engage in farming, fishing and trading to help their immediate families. As they do these they are also preparing themselves as responsible citizens of tomorrow.

Moreover, they learn a lot about ethical principles such as accepting responsibilities and how to live. Children working as domestic servants with wealthy families have the opportunities of learning to be good home keepers. In Nigeria, both in rural and urban settings, children work to help their families to relieve their parents form untold indebtedness. According to International Labour Organization, parents of child workers are often unemployed or underemployed. However, their children are offered jobs because children are cheaper and easier to exploit. As earlier posited, child labour has it negative consequences such as exploitation, physical and psychological abuse. The poor condition of the citizens especially in the third work countries has perpetuated this phenomenon. 
This paper advocates for an alternative dimension. Thus, the issue of proper planning and management becomes inevitable. This seems a more proper way of arresting the negative aspects of child labour. In the rural area where most of the children skip school on market days and during the planting and harvest seasons, the school curriculum can be modified to suit their absence. Child labour, according to Chess (2005), results in illiteracy, which is then passed from generations because the illiterate parents also send the children to work. Since a large percentage of the parents are poor, additional income to the family budget can only be boosted through child labour. Hence counselling becomes a proper channel for redirecting the phenomenon of child labour.

\section{Counselling Implications and Recommendations}

a. Films and video therapy could be used to reveal the need of these people who live under thatched roofs and have to scavenge to survive. The aim of such films is to get people to talk about what they think the status of poverty, child abuse and neglect and what can be done about it.

b. Different workshops and seminars are avenues for campaign. These seminars and workshops should be directed towards condemning child exploitation and to promote and provide positive child care and love. A variety of activities involves the collection of analysis and dissemination of information can be carried out through the media.

c. Campaign to enlighten the masses of skills of teaching the young should be encouraged. Values of work leading to selfreliance and self-sufficiency. Dignity of labour should be emphasized. The churches as well as clubs should be used as avenues.

d. Other avenues for campaign are Parents Teachers Association meetings and clubs like Lion and Rotary clubs. These help to teach people how they can use the children positively to contribute to the economic empowerment of families without injuring them physically and psychologically or depriving them of education. School represents the most important means of drawing children away from the labour market. It provides children with guidance and the opportunity to understand their roles in the society.

e. The federal Government has always assisted in the Universal Basic Education Level Programme both at the state and at the 
Local Government levels. Special schools for child workers are crucial so that they do not shift to more hazardous occupations. One necessary provision is that schools should be free. Children will not attend schools without an economic change in their condition. Specialization allows some children to acquire an education through support of their jobs and working siblings. Education and employment for children are not mutually exclusive. Government has to look into this and make provision for children who work to go to school at the same time. Non-governmental organizations should also come with new ideas to restore the parents' employment opportunity by suggesting to the respective governments to work with a commitment.

f. This should be directed towards a sustainable poverty reduction programme that will enable parents to send their children to school instead of labouring for the family. Economic development that assures adult a living wage would reduce the child work. Parents earn wages that will enable them cater for their children. In other words, there should be increased family income.

g. Law and sanction: Prohibiting the worst forms of child labour should be enacted. Working hours and work pace in harmony with their physical conditions, right of equal pay, right job training must not be denied children under the pretext that there working activities are anomalies. Bulato (1998) suggests that children should be involved in constructing solutions to their problems.

h. Curriculum that puts the victims of child labour into consideration should be encouraged. This curriculum for use in Nigerian schools should have a case of child work presented in all disciplines so that children can be enticed to return to school. This modified curriculum could consider the possibility of running shifts in our schools to accommodate the circumstance surrounding these children. For instance, in the riverine areas where fishing and farming are predominantly the main occupation, school time could be arranged to suit the seasons of planning and harvesting. This will enable the children to attend classes. With this, teachers in such areas will have to adjust the school periods to suit the children's availability. Moreover, education that helps children learn skills that will help them earn a living should equally be 
considered. Enterprise education should be co-opted into the curriculum.

i. Rehabilitation centres: Social services that will help children and families survive crises such as disease or loss of home and shelter should be provided, opportunities for interaction with children to settle down and manage their time. They should be integrated into school system to have formal education.

\section{Conclusion}

This paper has highlighted an alternative dimension to child labour. It has proffered that if the phenomenon is well managed, children can still go to school, contribute economically to the family, become self-reliant and self-fulfilled individuals. Child labour is actually becoming an evolutionary stage in the development of a country. Since it plays an instrumental role in economic survival of the family and the nation, it should be recognized to shop out its abuse.

\section{References}

Action Health Corporated (2002). Training Manual for Adolescent Friendly Health Service Ponders, Lagos. AHI.

Adegoke, A.A. (2003). Adolescent in Africa: Revealing the Problems of Teenagers in a Contemporary African Society, Ibadan, Hadassah Publishing.

Charles Dickens (1812-1870) Oliver Twist.

Chess, A. (2005) "Child Labour and Society" Website: http://www.chnnaionline.come./soiety/labour.

Cruzador P. (1998). Listen Children can Work? Newspaper on the $8^{\text {th }}$ Assembly of the World Council of Churches Number 9.

Dunapo, S.O. (2002). Causative and Sustaining Factors to Street Hawking in Nigeria: implications of the Nigerian child (ed.) Okonkwo, R.U.N \& Okenye, R.O.O Awka: Erudition Publishers.

Eweniyi, G.B. (2000). "Child Sexual Abuse and the Rights of the Nigerian Child in the" Counselor, 18 (1) 167-172.

Exceptional children (1994). Building Circle Piners Mirresota American Guich service, Inc.

Fatusi, A. Segun, B. Adeyemi, A. \& Odujinrun, S. (2001). National Training Manual: Adolescent Health \& Development (2001), Abuja: SMAT Limited.

Gil, D.C. (1990). Violence against Children Physical Child Abuse in the United States Cambridge Harvard Press. 
Hodges, A. (2001). Children and women Rights in Nigeria. a wake up call National Planning Commissions, Abuja and UNICEF Nigeria

Human Rights Watch Publication (2000). The Dawn of New Dark Age, Human Rights Watches New York. 